\title{
Spontaneous rupture of pancreatic pseudocyst into the stomach
}

\author{
Sharath P Madhyastha (10 ,' Giridhar Reddy Banda, ${ }^{1}$ Raviraja V Acharya, ${ }^{1}$ \\ Girisha Balaraju
}

'Internal Medicine, Kasturba Medical College, Manipal Academy of Higher Education, Manipal, Karnataka, India ${ }^{2}$ Gastroenterlogy, Kasturba Medical College, Manipal Academy of Higher Education, Manipal, Karnataka, India

Correspondence to Dr Sharath P Madhyastha; dr.sharathymc@gmail.com

Accepted 8 July 2021

\section{DESCRIPTION}

A 27-year-old man presented to the emergency department with sudden onset of haematemesis. There was no significant medical history. He was a chronic alcoholic for 9 years, consuming around $80 \mathrm{~g}$ of whisky on most of the days. On examination, he was pale and his vital signs were stable. There was mild tenderness noted over the epigastric region of the abdomen. Other systemic examinations were unremarkable. His haemoglobin at the time of admission was $56 \mathrm{~g} / \mathrm{L}$ (normal range: $130-160 \mathrm{~g} / \mathrm{L})$, renal and liver function tests, serum amylase $(79 \mathrm{U} / \mathrm{L})$ and lipase $(24 \mathrm{U} / \mathrm{L})$ levels were within normal limits. He was admitted to the hospital and two units of packed red blood cells were transfused.

Upper gastrointestinal endoscopy showed a large deep gastric ulcer with irregular edges over the greater curvature of the stomach, covered with black necrotic tissue (figure 1). CT of the abdomen revealed pancreatic pseudocyst, measuring $8.6 \times 7.4 \times 7.6 \mathrm{~cm}$ (figures 2 and 3), with rupture into the stomach (figure $2 \mathrm{~B}$, arrowhead). The patient was managed conservatively without surgical intervention. At follow-up in the outpatient clinic 2 weeks after discharge, he reported no symptoms and his repeat ultrasound abdomen showed a significant reduction in the size of the pseudocyst.

Pancreatic pseudocyst is a localised fluid collection as a result of acute or chronic pancreatitis and pancreatic trauma. These pseudocysts are collections of inflammatory pancreatic fluid lined by the granulation tissue. They are called 'pseudocysts' because there is no lining epithelium. Insult to the pancreatic duct during the inflammatory process leads to extravasation of pancreatic secretions and the development of a pseudocyst. ${ }^{1}$

The clinical presentation of pseudocyst may range from a completely asymptomatic patient to onset of serious complications. The most common presenting symptom is abdominal pain followed

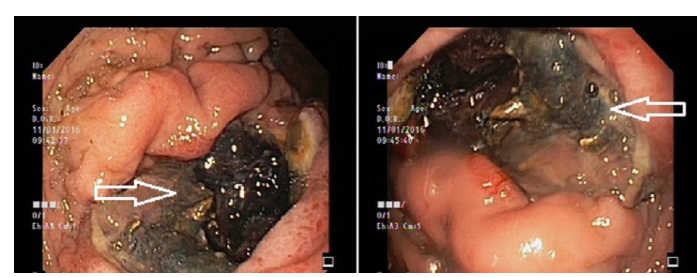

Figure 1 Endoscopic image showing a large deep ulcer with irregular edges, covered with slough and necrotic tissue, in the body of the stomach (arrows).
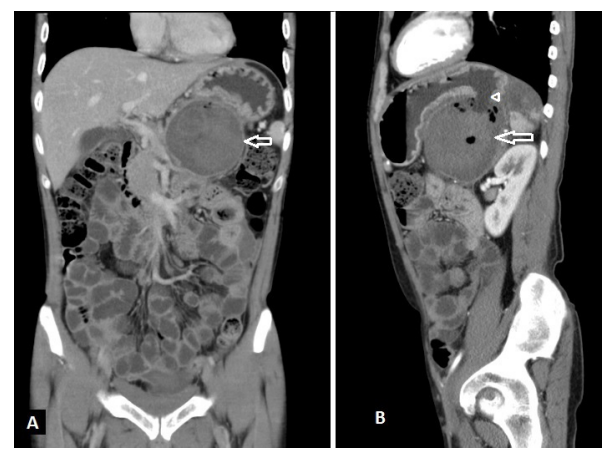

Figure 2 Contrast-enhanced CT of the abdomen (A) coronal and (B) sagittal views showing pancreatic pseudocyst, measuring $8.6 \times 7.4 \times 7.6 \mathrm{~cm}$ (arrows), with rupture into the stomach $(B$, arrowhead).

by a palpable mass, vomiting (due to compression of the stomach), jaundice (due to compression of the bile duct) and bleeding. Increase in serum lipase and amylase levels are seen in at least one-half of patients, and a persistent rise in these pancreatic enzymes can be a clue to the presence of a pseudocyst. The diagnosis of pseudocyst is generally made through abdominal imaging studies. ${ }^{2}$

More than one-third of pancreatic pseudocysts resolve spontaneously. Only a few cases can present with complications, which includes infection, fistula formation into hollow viscus and compression of adjacent structures. Usually, fistula drains into the transverse colon, splenic flexure or duodenum and very rarely into the stomach. Spontaneous rupture or fistula formation occurs in less than $3 \%$ of pancreatic pseudocysts. ${ }^{23}$

Management of pancreatic pseudocyst fistula depends on the site where it drains. Surgical interventions may be required if it drains into the duodenum or colon. Spontaneous rupture into the

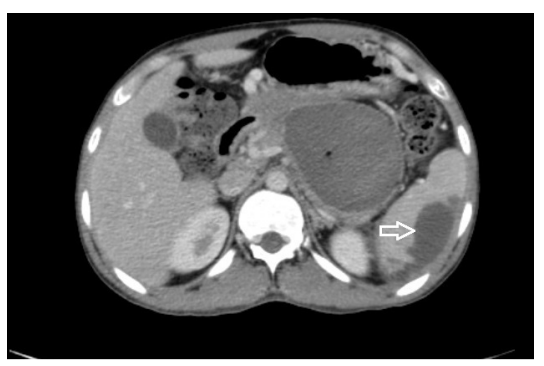

Figure 3 Pancreatic pseudocyst in the axial view of CT abdomen. Also, note multiple wedge-shaped splenic infarcts (arrow) 


\section{Learning points}

Spontaneous rupture of a pancreatic pseudocyst into the stomach is extremely rare.

- Such cases usually present with an upper gastrointestinal bleed and a majority of them subside by conservative management.

stomach usually subsides by conservative treatment unless the patient is actively bleeding. Active bleeding can be managed either by endoscopic clipping of bleeding vessels or by surgical intervention. Radiological or ultrasound-guided endoscopic embolisation is an alternative intervention in case of bleeding. ${ }^{34}$

Acknowledgements We acknowledge the Department of Radiology for providing CT abdomen images.

Contributors SPM and GRB wrote the draft of the manuscript. GB did the endoscopy and provided the endoscopy pictures. RA was involved in patient management and revised the manuscript critically for important intellectual content. All authors contributed to the literature review and approved the final manuscript for submission.

Funding The authors have not declared a specific grant for this research from any funding agency in the public, commercial or not-for-profit sectors.

Competing interests None declared.

Patient consent for publication Obtained.

Provenance and peer review Not commissioned; externally peer-reviewed.

ORCID iD

Sharath P Madhyastha http://orcid.org/0000-0003-2821-3473

\section{REFERENCES}

1 Habashi S, Draganov PV. Pancreatic pseudocyst. World I Gastroenterol 2009;15:38-47.

2 Somani PO, Jain SS, Shah DK, et al. Uncomplicated spontaneous rupture of pancreatic pseudocyst into stomach: a case report. World I Gastrointest Endosc 2013:5:461-4.

3 Kanaan Z, Zhang A, Lilley K, et al. Uncomplicated spontaneous rupture of a pancreatic pseudocyst into the stomach through a fistula: a case report and review of the literature. Pancreas 2018;47:e22-4.

4 Matsuoka L, Alexopoulos SP. Surgical management of pancreatic pseudocysts. Gastrointest Endosc Clin N Am 2018;28:131-41.

Copyright 2021 BMJ Publishing Group. All rights reserved. For permission to reuse any of this content visit

https://www.bmj.com/company/products-services/rights-and-licensing/permissions/

BMJ Case Report Fellows may re-use this article for personal use and teaching without any further permission.

Become a Fellow of BMJ Case Reports today and you can:

- Submit as many cases as you like

- Enjoy fast sympathetic peer review and rapid publication of accepted articles

- Access all the published articles

- Re-use any of the published material for personal use and teaching without further permission

\section{Customer Service}

If you have any further queries about your subscription, please contact our customer services team on +44 (0) 2071111105 or via email at support@bmj.com.

Visit casereports.bmj.com for more articles like this and to become a Fellow 